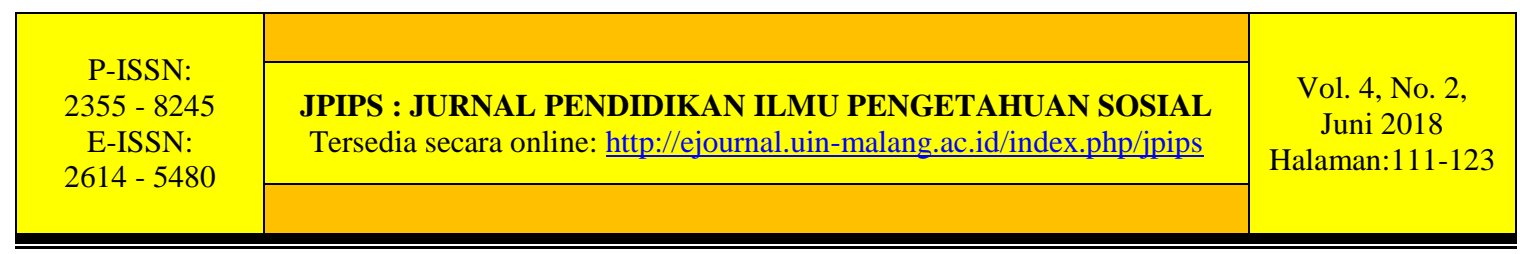

\title{
WONDERSHARE QUIZ CREATOR BERBASIS ANDROID DALAM MATA PELAJARAN SOSIOLOGI KELAS XI IPS 2 MAN 1 MALANG
}

\author{
Achmad Kholid Fadlullah \\ Universitas Islam Negeri Maulana Malik Ibrahim Malang \\ achmad_cholid@gmail.com
}

\begin{abstract}
Abstrak: Kualitas pendidikan ditentukan oleh keterpaduan antara seluruh komponen pembelajaran seperti guru, sarana pra sarana, kurikulum, metode pembelajaran, media pembelajaran. Pemanfaatan media merupakan salah satu upaya untuk mengatasi permasalahan pembelajaran. Media berfungsi sebagai perantara antara pendidik dan siswa dalam menyampaikan informasi. Untuk mencapai tujuan tersebut maka peneliti mengembangkan suatu media yaitu media evaluasi Wondershare Quiz Creator berbasis android. Tujuan penelitian ini adalah 1) Untuk mendeskripsikan spesifikasi media evaluasi Wondershare Quiz Creator berbasis android dalam mata pelajaran Sosiologi di kelas XI IPS 2 MAN 1 Malang. 2) Untuk mengembangkan media evaluasi Wondershare Quiz Creator berbasis android dalam mata pelajaran Sosiologi di kelas XI IPS 2 MAN 1 Malang. 3) Untuk mendeskripsikan hasil pengembangan pengembangan media evaluasi Wondershare Quiz Creator berbasis android dalam mata pelajaran Sosiologi di kelas XI IPS 2 MAN 1 Malang. Metode penelitian menggunakan pengembangan atau Reserch and Development (R\&D), mengacu pada model yang dikenalkan oleh Borg and Gall. Teknik pengumpulan data melalui observasi, tes dan angket. Teknik analisis data menggunakan analisis isi pembelajaran dan analisis deskriptif. Hasil penelitian ini menunjukkan bahwa: 1) media evaluasi Wondershare Quiz Creator berbasis android dalam pembelajaran sosiologi adalah sebuah aplikasi yang berisi berbagai variasi soal, bersifat random, dapat digunakan secara online dan offline. 2) media evaluasi Wondershare Quiz Creator yang awalnya berbasis web dalam computer dikembangkan menjadi aplikasi yang berbasis android 3) pengembangan ini terbukti efektif, menarik dan valid dalam, berdasarkan data validator ahli materi sosiologi $80 \%$, ahli desain $73 \%$, serta tanggapan siswa IPS $282,57 \%$. Adapun peningkatan hasil belajar pre-test dan post-test dari hasil uji-t Thitung $>$ Ttabel adalah $3,23>1,68$. Hal ini menunjukan bahwa produk yang dikembangkan memiliki tingkat validitas yang tinggi dan kemenarikan yang tinggi, sehingga layak digunakan dalam menunjang proses evaluasi.
\end{abstract}

\section{Kata Kunci : Wondershare Quiz Creator, Android, Mata Pelajaran Sosiologi.}

Abstract: The quality of education is determined by the integration between all learning components such as teachers, pre-facility facilities, curriculum, learning methods, learning media. The use of media is an effort to overcome learning problems. The media functions as an intermediary between educators and students in conveying information. To achieve this goal, the researchers developed a media that is an Android-based Wonder share Quiz Creator evaluation media. The purpose of the research is 1) To describe the specifications of the evaluation media for Wonder share Quiz Creator based on Android in Sociology subjects in XI IPS 2 MAN 1 Malang. 2) To 
develop an Android-based Wonder share Quiz Creator evaluation media in Sociology subjects in XI IPS 2 MAN 1 Malang. 3) To describe the results of the development of an Android-based Wonder share Quiz Creator media evaluation in Sociology subjects in XI IPS 2 MAN 1 Malang. The research method uses Research and Development $(R \&$ $D)$, referring to the model introduced by Borg and Gall. Techniques for collecting data through observation, tests, and questionnaires. Data analysis techniques used content analysis of learning and descriptive analysis. The results of this study indicate that: 1) Android-based Wonder share Quiz Creator evaluation media in sociology learning is an application containing's a variety of questions, random in nature, can be used online and offline. 2) Wonder share Quiz Creator media evaluation which was initially webbased in the computer was developed into an Android-based application 3) this development proved useful, interesting and valid in, based on $80 \%$ sociology material validator data, $73 \%$ design experts, and IPS 2 student responses $82.57 \%$. The increase in learning outcomes pre-test and post-test from the results of t-test, $T$ table is 3.23> 1.68. This shows that the product developed has a high level of validity and high attractiveness, so it is suitable to be used in supporting the evaluation process.

\section{Key words: Wonder share Quiz Creator, Android, Social Science}

\section{PENDAHULUAN}

Pendidikan memiliki makna yang sangat penting dalam kehidupan. Makna penting pendidikan ini telah menjadi kesepakatan yang luas dari setiap elemen masyarakat. Rasanya, tidak ada yang mengingkari apalagi menolak, terhadap arti penting dan segnifikasi pendidikan terhadap individu dan juga masyarakat. Lewat pendidikan bisa diukur maju mundurnya sebuah negara. Sebuah negara akan tumbuh pesat dan maju dalam segenap bidang kehidupan jika ditopang oleh pendidikan yang berkualitas. Sebaliknya, kondisi pendidikan yang kacau dan amburadul akan berimplikasi pada kondisi negara yang carut-marut (As'ari Muhajir, Ilmu Pendidikan Perspektif Kontekstual (Jogjakarta: AR-RUZ MEDIA, 2011).

Dunia pendidikan tidak terlepas dari berbagai komponen pembelajaran. Mulai dari guru, sarana pra sarana, kurikulum, metode pembelajaran, media pembelajaran dan lain-lain. Oleh karena itu kualitas pendidikan sebenarnya ditentukan oleh keterpaduan antar seluruh komponen pembelajaran. Hal ini senada dengan pendapat khanifatul dalam bukunya pembelajaran inovatif "dalam dunia pendidikan, peserta didik yang melakukan proses belajar, tidak melakukannya secara individu, tetapi ada beberapa komponen yang terlibat, seperti pendidik atau guru, media, strategi pembelajaran kurikulum dan sumber belajar (Khanifatul, Pembelajaran Inovatif (Jogjakarta: AR-RUZ MEDIA, 2013) .

Perkembangan ilmu pengetahuan dan teknologi dari waktu ke waktu selalu mengalami perubahan yang semakain pesat. Fenomena tersebut mengakibatkan adanya persaingan dalam bidang kehidupan. Salah satu dia antaranya adalah bidang pendidikan. Untuk mencetak sumber daya manusia (SDM) yang berkualitas diperlukan adanya peningkatan mutu pendidikan. Dalam hal ini kesuksesan dan keberhasilan suatu pendidikan tidak terlepas dari peran sekolah, baik sekolah negeri maupun swasta. Dengan berkembangnya ilmu pengetahuan dan teknologi ini, khususnya teknologi informasi, sangat berpengaruh terhadap penyusunan dan implementasi strategi pembelajaran melalui kemajuan tersebut para guru dapat menggunakan berbagai media sesuai dengan kebutuhan dan tujuan pembelajaran. Dengan menggunakan media, 
komunikasi tidak hanya dapat mempermudah dan mengefektifkan proses pembelajaran, akan tetapi juga bisa membuat proses pembelajaran menjadi lebih menarik (Wina Sanjaya 2008). Pemanfaatan media dalam proses pembelajaran merupakan salah satu upaya untuk mengatasi keadaan dalam proses pembelajaran, mengingat fungsi media dalam proses pembelajaran sangatlah baik untuk stimulus peningkatan keserasian terutama dalam menerima informasi. Sehingga media juga berfungsi sebagai perantara.

Perkembangan media perlu dilakukan guna mengatasi kesenjangan, perkembangan yang dirasa memungkinkan dan sesuai untuk keadaan adalah pembuatan multimedia interaktif. Di mana media ini dipilih berdasarkan angapan yang menyatakan bahwa manusia memiliki dua sistem pemprosesan informasi, yakni materi-materi verbal dan materi-materi visual (Mayer, 2009). Visual dan verbal erat kaitanya dengan multimedia yang identik dengan kata-kata dan gambar, sehingga media semacam ini dapat memanfaatkan kedua kapasitas menusia sepenuhnya untuk memproses informasi. Suyanto (2003) mengatakan bahwa multimedia menjadi penting karena dapat dipakai sebagai alat persaingan. Disamping itu multimedia melakukan hal ini bukan hanya dengan menyediakan lebih banyak teks, melainkan juga dengan menghidupkan teks yang disertai bunyi, gambar, musik, animasi, dan video (Binanto, 2010). Sehingga peserta didik sebagai sasaran utama dalam pembelajaran media sangatlah membantu mereka untuk kegiatan belajar dan nantinya akan membuat hasil belajar tersebut semakin baik. Selain itu, menurut Walter (Candra dan Achadiyah, 2014) di banyak negara, penilaian berbasis komputer telah menjadi standar dan menjadi semakin menarik untuk departemen pendidikan, legislatif dan pembuat kebijakan lainnya.

Dalam dunia pendidikan, jika kita lihat pada proses pembelajaran, sudah banyak sekali media interaktif yang diciptakan oleh pendidik guna untuk memudahkan pendidik dalam menyampaikan materi pembelajaran yang dapat difahami oleh murid secara mudah. Sedangkan salah satu penunjang keberhasilan dalam proses pembelajaran ialah adanya proses evaluasi sebagai tolok ukur kemampuan peserta didik dari hasil proses pembelajaran yang telah ditempuh oleh pendidik dan peserta didik.

Proses evaluasi yang sering kita lihat di sekolah-sekolah dari dulu hingga sekarang nampaknya sangatlah monoton. Hanya menggunakan kertas soal dan kertas jawaban yang disebar ke setiap peserta didik. Dengan model seperti ini murid sudah sangat merasa bosan dan merasa lebih tegang dalam menghadapi soal-soal ketika proses evaluasi berlangsung. Peserta didik pun dengan leluasa dapat melakukan kecurangan, seperti mencontek dan lain-lain. Hal ini dapat menyebabkan keadaan kelas tidak kondusif lagi. Dan dengan kejadian diatas, tujuan dari evaluasi yakni mengukur kemapuan peserta didik dari apa yang telah didapat selama proses pembelajranpun tidak dapat diperoleh guru secara valid.

Hal ini pun terjadi di MAN 1 Malang khususnya kelas XI IPS 2 dalam pembelajaran sosiologi. Guru seringkali kewalahan ketika mengadakan evaluasi terhadap peserta didik dan hasilnya pun tidak memuasakan, sehingga tujuan dari proses pembelajaranpun tidak tercapai.

Dengan adanya masalah di atas peneliti ingin mengembangkan media yang dapat merubah maindset peserta didik terhadap proses evaluasi dan membuatnya menjadi efisien ketika digunakan. Peneliti inin mengembangkan media evaluasi berbasis Wondershare Quiz Creator yang di dalamnya terdapat banyak model-model soal yang mana guru dapat mengkrasikannya menjadi sangat menarik. Dalam mengerjakan soalsoal pendidik mematok waktu yang bisa diseting langsung dari media tersebut. Soal- 
soalpun dapat dibuat random (acak) sehingga antara satu siswa dengan siswa lainnya sulit untuk mencontek.

\section{METODE}

Jenis penelitian ini merupakan jenis pengembangan yang berorientasi pada produk dalam bidang pendidikan. Menurut Nana Syaodi Sukmadinata dalam bukunya yang berjudul metode penelitian pengembangan atau Reserch and Development (R\&D) adalah sebuah strategi atau metode penelitian yang cukup ampuh untuk memperbaiki praktek (Sukmadinata, 2007). Instrument penelitian yang digunakan seperti berikut: 1) observasi 2) angket 3) tes.

Model pengembangan yang dilakukan dalam penelitian ini mengacu pada model penelitian dan pengembangan yang dikenalkan oleh Borg and Gall.

Langkah-Langkah Pengembangan Borg And Gall
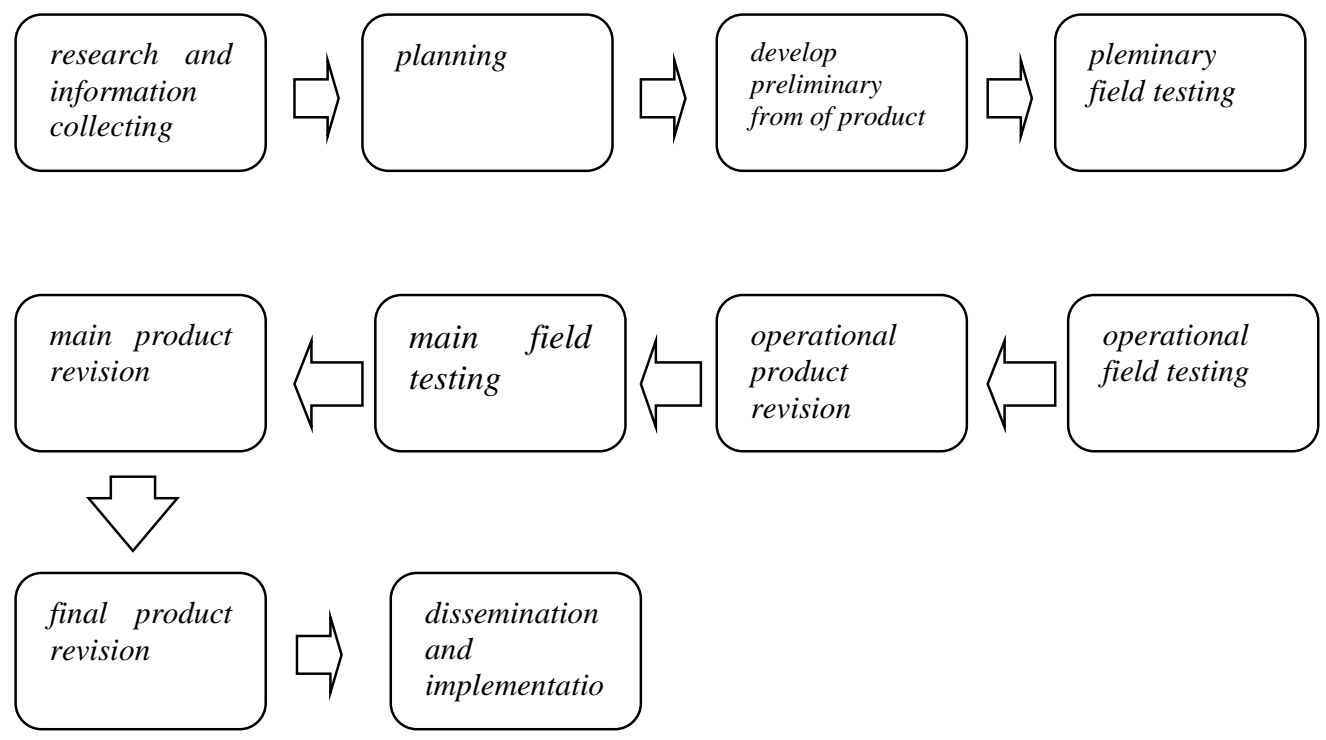

\section{HASIL DAN PEMBAHASAN \\ Hasil}

\section{Deskripsi Spesifikasi Media Evaluasi WQCreator berbasis android}

Wondershare Quiz Creator was software for making uestions uizzes or test online (web-based) (Sangkala, 2014). Wondershare Quiz Creator merupakan perangkat lunak untuk pembuatan soal, kuis atau tes secara online (berbasis web). Wondershare Quiz Creator juga dapat dikembangkan secara online melalui blog, seperti penelitian yang dilakukan oleh Kuswari (2009), Wondershare Quiz Creator merupakan perangkat lunak untuk pembuatan soal, kuis, atau tes online. Hasil soal, kuis dan tes dibuat/disusun dengan perangkat lunak ini dapat disimpan dalam format Flash yang dapat berdiri sendiri (stand alone) di website.

\section{Pengembangan Produk Media Evaluasi WQC Berbasis Android}

Evaluasi sistem pembelajaran merupakan komponen penting untuk menentukan keefektifan pembelajaran (Zainal Arifin, 2012). Evaluasi merupakan bagian integral dari suatu proses pembelajaran. Idealnya, efektifitas pelaksanaan proses pembelajaran diukur dari dua aspek, yaitu: bukti-bukti empiris mengenai hasil belajar siswa yang dihasilkan oleh sistempembelajaran, dan (2) bukti-bukti yang mnunjukkan berapa 
banyak kontribusi (sumbangan) media atau media program terhadap keberhasilan dan keefektifan proses embelajaran itu (Kustandi, 2011). Pengembangan ini menghasilkan media evaluasi Wondershare Quiz Creator berbasis android berbentuk aplikasi yang terdapat dalam hp android. Media ini dibuat dengan mengconvert media yang berbasi computer menjadi android dengan menggunakan Http://appsgeyser.com. Desain pembelajaran berbasis komputer memiliki berbagai keunggulan, di antaranya cara kerja meningkatkan motivasi, grafis memberikan efek nyata, respon pribadi cepat, kemampuan memori untuk menangkap media cepat, dan berguna untuk pembelajar yang lamban (Piyanto, 2009)

Data validasi terhadap media evaluasi wondershare Quiz Creator berbasis android ini di peroleh dari evaluasi yang di lakukan oleh dua validator ahli, yaitu terdiri dari validator materi dan validator desain media. Peneliti juga menjadikan guru sebagai sumber informasi yang menjadi landasan dalam penelitian ini. Selain para ahli dan guru peneliti juga menjadikan siswa sebagai objek validator terhadap media yang mereka coba. Dan yang di peroleh merupakan data kuantitatif dan kualitatif. Data kuantitatif berasal dari angket penilaian dengan menggunakan rumus skala Likert, sedangkan data kualitatif berupa penilaian tambahan atau saran dari validator.

\section{Penyajian Hasil Pengembangan Media Evaluasi WQC Berbasis Android}

Data yang di peroleh dari penelitian ini terdiri dari dua macam, yakni data kuantitatif dan data kualitatif. Data tersebut di peroleh melalui tahap penelitian yaitu validitas ahli dan uji coba lapangan.

\section{Pembahasan \\ Analisis Spesifikasi Hasil Pengembangan media evaluasi Wondershare Quiz Creator berbasis android}

Produk yang dikembangkan berupa Media Evaluasi Wondershare Quiz Creator berbasis android dalam mata pelajaran sosiologi di kelas XI IPS 2 MAN 1 Malang.

1. Analisis Langkah Pengembangan Media Evaluasi Wondershare Quiz Creator berbasis android.

Berdasarkan sepuluh langkah dari Model Borg and Gall (Setyosari, 2010), peneliti mengadobsi menjadi enam langkah. Enam langkah tersebut akan diperinci sebagai berikut.

a. Tahap Analisis Kebutuhan dan Perencanaan. Tahap ini dilakukan untuk memberikan gambaran umum tentang kondisi dilapangan. Gambaran umum tersebut akan dapat mencerminkan masalah yang dihadapi dilapangan. Ini penting dilakukan guna penelitian dan pengembangan menjadi tepat sasaran dan sesuai dengan kondisi dilapangan. Dalam tahap ini peneliti membagi menjadi tiga langkah.

1) Observasi

Observasi dilakukan dengan melihat pembelajaran secara langsung dan melakukan wawancara terhadap guru bidang studi.

2) Mengkaji Kurikulum

Kurikulum 2013 dikaji mulai dari kompetensi inti dan kompetensi dasar. Dari kajian ini didapatkan bahwa kompetensi inti kurikulum 2013 memiliki empat komponen yaitu spiritual, afektif, kognitif, dan psikomotorik. Setelah itu, dengan melihat bahan ajar yang tersedia disekolah terdapat kejanggalan atau masalah yang sangat mendasar namun sangat berpengaruh dalam proses pembelajaran sosiologi di dalam kelas. Yakni adanya kejenuhan terhadap sistem atau dalam 
pelaksanaan proses evaluasi. Dengan cara dan media yang seperti biasanya, murid cenderung bosan dan mudah melakukan kecurangan saat mengerjakan soal-soal, hingga tujuan dalam melaksanakan proses evaluasi tidak tercapai secara maksimal.

3) Menyusun Rancangan Produk

Tahap ini dilakukan dengan menyiapkan konsep media yang akan dikembangkan. Pengembangan itu berupa Media Evaluasi Wondershare Quiz Creator berbasis android. Konsep Media Evaluasi ini dibuat dengan tujuan untuk menyisipkan aspek psikomotorik dalam kurikulum 2013. Untuk mewadahi itu, digunakan Media Evaluasi Wondershare Quiz Creator berbasis android sebagai media dalam pelaksanaan proses evaluasi. Ini karena sifat media evaluasi yang lalu sangatlah membosankan, rumit dan terdapat beberapa masalah yang mengakibatkan tujuan dari pelaksanaan evaluasi tersebut tidak dapat tercapai.

b. Tahap Pengembangan. Pada tahap ini terbagi atas dua langkah yang secara terperinci akan dijelaskan sebagai berikut.

1) Menyusun struktur media

Langkah ini dilakukan dengan mengumpulkan berbagai materi baik materi ajar dan gambar yang akan digunakan dalam media evaluasi Wondershare Quiz Creator berbasis android.

2) Menyusun Media

Langkah ini dimulai dengan menyiapkan materi berupa materi sosiologi kelas XI IPS. Setelah materi terkumpul, langkah selanjutnya adalah membuat soal-soal yang akan menjadi isi dari media evaluasi Wondershare Quiz Creator berbasis android. Langkah terakhirnya adalah mendesain media dengan tampilan dan susunan yang menarik.

c. Validasi dan Revisi Produk

Dalam validasi, pengembang mengambil dua ahli validator, yang terdiri atas ahli materi sosiologi dan ahli desain media. Pada tahap ini validator ahli materi sosiologi dan ahli desain media memberikan penilaian terhadap media evaluasi dalam bentuk angket yang disebarkan, serta memberikan masukan dan saran terhadap media evaluasi. Setelah itu, pengembang merevisi produk sesuai dengan masukan dan saran dari validator. Setelah direvisi, produk dikonsultasikan ulang, guna mendapat penilaian dan saran kembali supaya produk benar-benar sempurna.

d. Uji Coba Lapangan

Dalam tahap ini, pengembang melakukan dua langkah yang terdiri atas pengenalah produk dan tata cara penggunaan media evaluasi, dan uji coba produk media evaluasi terhadap peserta didik. Dala pengenalan media, siswa diberi penjelasan tentang macam-macam jenis soal yang ada dalam media evaluasi wondershare quiz creator ini, yang mana di dalamnya terdapat enam macam jenis soal yaitu: multiple choice, multiple respon, true and fals, matching, squance, shoot. Setelah diberi penjelas tentang isi dan tata cara penggunaan media, siswa langsung mencoba media evaluasi tersebut. Dalam enelitian ini, peneliti mencantumkan 25 butir soal yang terdiri dari enam jenis soal seperti yang sudah dijelaskan di atas. Setelah itu siswa diberi angket untuk memberi penilaian tentang media evaluasi dengan perbandingan terhadap media atau alat-alat yang pernah digunakan sebelumnya dalam proses evaluasi.

e. Produksi Akhir 
Tahap terakhir ini dimaksudkan dengan menuliskan laporan sesuai dengan prosedur yang telah ditentukan. Dan memproduksi ulang media evaluasi Wondershare Quiz Creator berbasis android dalam pembelajaran sosiologi sesuai dengan kebutuhan.

\section{Analisis Pengembangan Produk Media Evaluasi Wondershare Quiz Creator Berbasis Android}

Pengembangan ini menghasilkan media evaluasi Wondershare Quiz Creator berbasis android berbentuk aplikasi yang terdapat dalam hp android. Media ini termasuk dalam e-learning, dimana penggunaannya berbasis elektroni. Media ini dibuat dengan mengconvert media yang berbasi computer menjadi android dengan menggunakan Http://appsgeyser.com. media ini dikembangkan dengan tujuan untuk memberikan variasi dalam proses pelaksanaan evaluasi yang selama ini cenderung monoton dan kurang menarik. Media ini juga dapat membantu guru agar lebih mudah dalam mengoreksi dan mendapatkan hasil murni kerja siswa selama proses pembelajaran yang telah berlalu. Seperti penelitian yang dilakukan oleh Hanum (2013) menunjukkan bahwa evaluasi belajar dengn e-learning menunjukkan kategori cukup efektif dengan kecenderungan sebesar 60,01\%. Selain itu, menurut (Utomo \& Kustijono, 2015) dari segi waktu yang digunakan cukup efektif dengan hasil waktu pengerjaan sebagian besar siswa dibawah waktu yang ditentukan. Hal ini dikarenakan berkurangnya kecurangan dengan fokus pada soal yang ada dihadapinya karena ada hitung waktu mundur.

Materi dari soal-soal yang ada dalam media ini diambil dari buku paket yang siswa gunakan selama proses pembelajaran berlangsung. Materi soal-soal yang dibuat diambil dari Bab 1 yang berjudul kelompok sosial. Sedangkan jumlah jenis atau model soal yang ada di dalam madia ini adalah enam jenis soal. Dan dengan penjelasan dan arahan yang jelas, sehingga siswa dapat dengan mudah menggunakan aplikasi ini.

Selain itu, tujuan khusus dari media evaluasi ini adalah untuk mendapatkan hasil dari proses evaluasi yang murni pada siswa. Selain itu juga, media evaluasi ini juga sebagai alat pengukur kemampuan siswa setelah diadakannya proses pembelajaran yang sangat efektif. Dalam hal ini, guru pun tidak perlu mengoreksi hasil kerja siswa, karena dengan sendirinya nilai siswa akan terkirim ke email guru. Oleh karena itu, sesuai manfaat evaluasi pembelajaran online (Setemen, 2010) bahwa sistem evaluasi ini mampu menangani proses evaluasi pembelajaran dengan bentuk tes pilihan ganda, hasil skor yang diperoleh langsung dapat dilihat oleh siswa setelah selesai melakukan tes.

Mengacu dari tujuan di atas, diharapkan nilai murid dapat meningkat karena motivasi dalam mengerjakan soal pun meningkan karena adanya media evaluasi yang menarik ini. Karena dalam media evaluasi ini menyempitkan peluang siswa untuk melakukan kecurangan dalam mengerjakan soal-soal, guru pun dengan otomatis akan mendapatkan hasil nilai dari murid yang murni. Hingga dapat menunjang proses pembelajaran menjadi lebih baik lagi.

Untuk mencakapi tujuan tersebut, media evaluasi dikembangkan dengan tampilan yang menarik. Tampilan menarik tersebut dapat berupa desain yang menarik, tata letak yang tepat, penambahan gambar, jenis-jenis soal yang bervariasi. Hal ini dimuat dalam media untuk menambah tingkat kemenarikan media. Selain itu, untuk mencapai tujuan khususnya, media dilengkapi ruang untuk mempelajari ulang soal-soal yang telah dijawab. Latihan soal yang dimuat dalam media dimaksudkan supaya siswa mampumempelajari ulang kesalahan-kesalahan ketika pengerjaan soal yang telahdilakukan sebelumnya. terjadi mengukur kemampuannya secara mandiri setelah 
selesai menggunakan modul. Dalam latihan soal ini juga dilengkapi dengan kunci jawaban. Kunci jawaban ini berguna untuk siswa mengoreksi jawaban yang salah tadi.

\section{Analisis Hasil Pengembangan Produk Media Evaluasi Wondershare Quiz Creator Berbasis Android}

\section{Tingkat Validitas}

Hasil validasi dari beberapa ahli telah dikonservasikan pada skala persentase berdasarkan pada tingkat kevaliditasan serta pedoman untuk merevisi bahan ajar yang dikembangkan dengan tingkat pencapaian sebagai berikut.

Tabel 1. Kualifikasi Tingkat Kelayakan Berdasarkan Persentase

\begin{tabular}{ccc}
\hline Persentase & Tingkat Kevalidan & Keterangan \\
\hline $85-100 \%$ & Sangat Valid & Tidak direvisi \\
$69-84 \%$ & Valid & Tidak direvisi \\
$53-68 \%$ & Cukup Valid & Direvisi sebagian \\
$37-52 \%$ & Kurang Valid & Revisi \\
$21-36 \%$ & Sangat Kurang Valid & Revisi total \\
\hline
\end{tabular}

a. Analisis Hasil Validasi Ahli Materi Sosiologi

Berikut merupakan paparan data hasil validasi ahli materi Sosiologi.

1) Tingkat relevansi media evaluasi dengan kurikulum yang berlaku dalam kurikulum 2013 di kelas XI diperoleh nilai dengan persentase 80\%. Hal ini menunjukan bahwa adanya relevansi media evaluasi dengan kurikulum yang berlaku dalam kurikulum 2013 di kelas XI.

2) Kesesuaian antara isi latihan dan tujuan pembelajaran diperoleh nilai dengan persentase $80 \%$. Hal ini menunjukan bahwa adanya Kesesuaian antara isi latihan dan tujuan pembelajaran.

3) Kejelasan uraian soal-soal sesuai dengan kompetensi dasar diperoleh penilaian dengan persentase $80 \%$. Hal ini menunjukan bahwa uraian soal-soal sesuai dengan kompetensi dasar.

4) Kejelasan uraian soal-soal sesuai dengan indicator pembelajaran diperoleh penilaian dengan persentase $80 \%$. Hal ini menunjukan bahwa uraian soal-soal sesuai dengan indicator pembelajaran.

5) Kejelasan uraian soal-soal sesuai dengan tujuan pembelajaran diperoleh penilaian dengan persentase $100 \%$. Hal ini menunjukan bahwa uraian soalsoal sesuai dengan tujuan pembelajaran.

6) Kejelasan uraian soal-soal sesuai dengan evaluasi dalam pembelajaran diperoleh penilaian dengan persentase $100 \%$. Hal ini menunjukan bahwa uraian soal-soal sesuai dengan evaluasi dalam pembelajaran telah jelas.

7) Kesesuaian refrensi yang digunakan dalam bidang ilmu diperoleh penilaian dengan persentase $80 \%$. Hal ini menunjukan bahwa refrensi yang digunakan dalam bidang ilmu telah sesuai dan memudahkan siswa dalam memahami materi untuk mengerjakan soal-soal media evaluasi Wondershare Quiz Creator.

8) Kelengkapan materi dalam media evaluasi Wondershare Quiz Creator diperoleh penilaian dengan persentase $80 \%$. Hal ini menunjukan bahwa materi dalam media evaluasi Wondershare Quiz Creator telah lengkap. materi yang dicantumkan dalam media ini haruslah lengkap dan mencakup aspek-aspek penting yang berhubungan dengan materi tersebut guna memberi pengetahuan yang lengkap kepada siswa. 
9) Keluasan dan kedalaman isi pada media evaluasi diperoleh penilaian dengan persentase $80 \%$. Hal ini menunjukan bahwa Keluasan dan kedalaman isi pada media evaluasi telah tercapai. Ini juga dapat dilihat dari nilai yang dicapai siswa ketika mengerjakan evaluasi dengan menggunakan media evaluasi ini.

10) Kesesuaian materi soal dengan karakteristik siswa diperoleh penilaian dengan persentase $80 \%$. Hal ini menunjukan bahwa materi soal dengan karakteristik siswa. Hal ini dianggap penting karena setiap siswa memiliki karakteristik yang berbeda-beda.

11) Soal-soal yang disajikan dalam media evaluasi mudah difahami diperoleh penilaian dengan persentase $80 \%$. Hal ini menunjukan bahwa Soal-soal yang disajikan dalam media evaluasi mudah difahami. Soal-soal yang ada dalam media ini haruslah mudah difahami oleh siswa, agar memudahkan mereka dalam menyelesaikan butir-butir soal yang ada di dalam media.

12) Kejelasan perintah dalam mengerjakan soal-soal diperoleh penilaian dengan persentase $80 \%$. Hal ini menunjukan bahwa perintah dalam mengerjakan soalsoal telah jelas, sehingga memudahkan siswa dalam mengerjakan soal-soal yang ada di dalam media ini.

13) Susunan kalimat yang digunakan dalam menyajikan materi pada media evaluasi Wondershare Quiz Creator mudah difahami diperoleh penilaian dengan persentase $80 \%$. Hal ini menunjukan bahwa Susunan kalimat yang digunakan dalam menyajikan materi pada media evaluasi Wondershare Quiz Creator.

14) Tingkat kesulitan latihan soal media evaluasi Wondershare Quiz Creator mudah difahami diperoleh penilaian dengan persentase $80 \%$. Hal ini menunjukan bahwa kesulitan soal media evaluasi yang ada jelas dan sesuai dengan karakteristik siswa.

15) Ketepatan instrument evaluasi yang digunakan dapat mengukur kemampuan siswa diperoleh penilaian dengan persentase $80 \%$. Hal ini menunjukan bahwa instrument evaluasi yang digunakan dapat mengukur kemampuan siswa telah tepat. Instrument evaluasi yang digunakan haruslah tepat agar dapat menarik minat dan semangat siswa saat mengerjakan soal-soal.

Dari penilaian ahli desain tersebut, maka dapat dihitung persentase tingkat kevalidan media sebagai berikut :

$$
\begin{aligned}
\mathrm{P} & =\frac{\sum \mathrm{x} x}{\sum_{\mathrm{xi}} \mathrm{x}} \times 100 \% \\
& =\frac{60}{75 \mathrm{i}} \times 100 \% \\
& =80 \%
\end{aligned}
$$

Dari hasil perhitungan diatas menunjukan bahwa materi Sosiologi pada media evaluasi Wondershare Quiz Creator mendapatkan nilai 80\%. Hal ini berarti bahwa modul termasuk dalam kategori "valid".

b. Analisis Hasil Validasi ahli desain

Berikut merupakan paparan data hasil validasi ahli desain

1) Tampilan media evaluasi diperoleh penilaian dengan persentase $80 \%$. Hal ini menunjukan bahwa Tampilan media evaluasi Wondershare Quiz Creator sudah cukup menarik bagi siswa di tunjukan dengan hasil angket dari siswa.

2) Kejelasan petunjuk penggunaan media evaluasi diperoleh penilaian dengan persentase $80 \%$. Hal ini menunjukan Kejelasan petunjuk penggunaan media 
evaluasi sudah cukup jelas dengan petunjuk penggunaan media evaluasi yang sudah ada di dalam media evaluasi Wondershare Quiz Creator.

3) Desain tampilan media evaluasi Http://Appsgeyser.com sesuai dengan karakteristik siswa kelas XI diperoleh penilaian dengan persentase $80 \%$. Hal ini menunjukan bahwa Desain tampilan media evaluasi Http://Appsgeyser.com sudah sesuai dengan karakteristik siswa kelas XI.

4) Kejelasan tulisan atau pengetikan diperoleh penilaian dengan persentase $80 \%$. Hal ini menunjukan bahwa Kejelasan tulisan atau pengetikan sudah cukup jelas.

5) ketetapan penggunaan tema media evaluasi diperoleh penilaian dengan persentase $60 \%$. Hal ini menunjukan bahwa penggunaan tema di dalam media evaluasi Wondershare Quiz Creator sudah cukup valid.

6) Kemenarikan penggunaan warna yang digunakan dalam mendesain media evaluasi penilaian dengan persentase $60 \%$. Hal ini menunjukan bahwa sudah cukup valid Kemenarikan penggunaan warna yang digunakan dalam mendesain media evaluasi Wondershare Quiz Creator.

7) Kemudahan bahasa yang digunakan dalam media evaluasi diperoleh penilaian dengan persentase $80 \%$. Hal ini menunjukan bahwa Kemudahan bahasa yang digunakan dalam media evaluasi sudah cukup baik dengan hasil nilai yang di peroleh dari siswa yang sudah mencapai SKL.

8) Kesesuaian tampilan media dengan karakteristik siswa diperoleh penilaian dengan persentase $80 \%$. Hal ini menunjukan bahwa Kesesuaian tampilan media sudah sesuai dengan karakteristik siswa.

9) Kejelasan jenis-jenis soal diperoleh penilaian dengan persentase $60 \%$. Hal ini menunjukan bahwa Kejelasan jenis-jenis soal cukup valid.

10) Kejelasan bentuk soal diperoleh penilaian dengan persentase $60 \%$. Hal ini menunjukan bahwa Kejelasan bentuk soal cukup valid.

11) Kejelasan kunci jawaban pada uraian soal diperoleh penilaian dengan persentase $80 \%$. Hal ini menunjukan bahwa Kejelasan kunci jawaban pada uraian soal sudah jelas.

12) Kejelasan pedoman dalam pembuatan soal diperoleh penilaian dengan persentase $60 \%$. Hal ini menunjukan bahwa Kejelasan pedoman dalam pembuatan soal sudah cukup valid.

13) Kemudahan penggunaan media evaluasi diperoleh penilaian dengan persentase $80 \%$. Hal ini menunjukan bahwa siswa mampu menggunakan media evaluasi dengan baik.

14) Penggunaan variasi warna yang dipakai dalam media evaluasi Http://Appsgeyser.com diperoleh penilaian dengan persentase $80 \%$. Hal ini menunjukan bahwa penggunaan variasi warna di dalam media evaluasi sudah baik dan sesuai.

15) Media evaluasi sosiologi mampu meningkatkan motivasi siswa diperoleh penilaian dengan persentase $80 \%$. Hal ini menunjukan bahwa siswa sangat tertarik dengan media evaluasi Wondershare Quiz Creator.

16) Tampilan tombol/button/navigasi jelas diperoleh penilaian dengan persentase $60 \%$. Hal ini menunjukan bahwa Tampilan tombol/button/navigasi sudah cukup jelas terdapat di dalam media evaluasi.

17) Kombinasi teks, gambar dan warna dalam media evaluasi sosiologi serasi diperoleh penilaian dengan persentase $80 \%$. Hal ini menunjukan bahwa 
Kombinasi teks, gambar dan warna dalam media evaluasi sosiologi sudah serasi dan sesuai.

Dari penilaian ahli desain tersebut, maka dapat dihitung persentase tingkat kevalidan media sebagai berikut :

$$
\begin{aligned}
\mathrm{P} & =\frac{\sum \mathrm{x}}{\sum_{\mathrm{xi}}} \times 100 \% \\
& =\frac{62}{85} \times 100 \% \\
& =73 \%
\end{aligned}
$$

Dari hasil perhitungan diatas menunjukan bahwa desain media pada media evaluasi Wondershare Quiz Creator mendapatkan nilai 73\%. Hal ini berarti bahwa modul termasuk dalam kategori "valid".

\section{Tingkat Kemenarikan}

Pada uji kemenarikan ini hanya dilakukan pada satu kali uji di satu kelas yang berbeda. Adapun responden yang diambil dalam uji kemenarikan media ini berjumlah 36 untuk kelas XI IPS 2 responden yang terdiri atas siswa kelas XI IPS MAN 1 Malang. Berikut merupakan paparan data hasil uji kemenarikan terhadap media evaluasi Wondershare Quiz Creator .

a. Kelas XI IPS 2

1) Media ini sangat menarik diperoleh penilaian dengan persentase $92 \%$. Hal ini menunjukan bahwa media menarik bagi siswa untuk digunakan dalam evaluasi pembelajaran..

2) Media ini memiliki desain dan isi yang menarik diperoleh penilaian dengan persentase $85 \%$. Hal ini menunjukan bahwa isi dan desain sangat menarik dan mudah dipahami bagi siswa.

3) Media ini menambah semangat saya dalam menjawab soal-soal diperoleh penilaian dengan persentase $85 \%$. Hal ini menunjukan bahwa media ini menambah semangat bagi siswa dalam menjawab soal-soal karna mempunyai desain yang menarik.

4) Media ini memiliki materi dan isi yang mudah dimengerti diperoleh penilaian dengan persentase $79 \%$. Hal ini menunjukan bahwa Media ini memiliki materi dan isi yang mudah dimengerti untuk memudahkan siswa dalam dalam mengerjakan soal evaluasi..

5) Proses evaluasi menggunakan media seperti ini sesuai dengan minat diperoleh penilaian dengan persentase $85 \%$. Hal ini menunjukan bahwa Proses evaluasi menggunakan media evaluasi Wondershare Quiz Creator ini sesuai dengan minat siswa.

6) Media ini memiliki cara yang simple dalam menjawab soal diperoleh penilaian dengan persentase $82 \%$. Hal ini menunjukan bahwa Media ini memiliki cara yang simple dalam menjawab soal sehingga memudahkan siswa dalam menjawab soal-soal.

7) Proses evaluasi menggunakan media ini sangat menyenangkan dari pada menggunakan media yang pernah saya gunakan sebelumnya diperoleh penilaian dengan persentase $82 \%$. Hal ini menunjukan bahwa siswa lebih tertarik menggunakan media evaluasi Wondershare Quiz Creator dalam evaluasi pembelajaran karna media ini sangat menyenangkan dari pada menggunakan media yang pernah di gunakan sebelumnya.

8) Selama menggunakan media ini, siswa tidak memerlukan bantuan orang lain seperti teman atau guru diperoleh penilaian dengan persentase $70 \%$. Hal ini 
menunjukan bahwa media evaluasi ini memiliki cara penggunaan dan bahasa yang mudah, hingga siswa tidak memerlukan banyak bantuan dari guru di kelas dalam penggunaan media ini.

9) Dari penilaian kemenarikan modul tersebut dapat dihitung persentase kevalidan media sebagai berikut.

$$
\begin{aligned}
\mathrm{P} & =\frac{\sum \mathrm{x} x}{\sum \mathrm{xi}} \times 100 \% \\
& =\frac{155,25}{188} \times 100 \% \\
& =82,57 \%
\end{aligned}
$$

Dari hasil perhitungan diatas menunjukan bahwa modul integratif mendapatkan nilai $82,57 \%$. Hal ini berarti bahwa modul termasuk dalam kategori valid.

\section{KESIMPULAN}

Berdasarkan proses evaluasi dan hasil hasil uji coba media evaluasi Wondershare Quiz Creator pada juduk kelompok sosial kelas XI IPS 2, maka dapat dipaparkan sebagai berikut.

1. Proses pengembangan media evaluasi ini telah menyediakan aplikasi berupa media evaluasi yang basis android pada pelajaran sosiologi . Media evaluasi ini telah memenuhi unsur media yang baik dan benar. Hasil pengembangan ini telah mampu menjadikan media evaluasi Wondershare Quiz Creator sebagai bahan ajar penunjang bagi guru dan siswa kelas XI IPS 2 MAN 1 Malang.

2. Pengembangan media evaluasi berbasis android ini mencapai penilaian dari para ahli yang cukup tinggi yaitu dengan rata-rata $80 \%$. Adapun uraian hasilnya dapat disimpulkan sebagai berikut: Ahli materi sosiologi memberikan penilaian terhadap media evaluasi Wondershare Quiz Creator berbasis android persentase kevalidan mencapai $80 \%$ dengan kategori sangat valid, Ahli materi desain memberikan penilaian terhadap media evaluasi Wondershare Quiz Creator berbasis android persentase kevalidan mencapai $73 \%$ dengan kategori sangat valid, Subjek uji coba yakni kelas XI IPS 2 memberikan penilaian terhadap media evaluasi Wondershare Quiz Creator berbasis android persentase kevalidan mencapai 82,57\% dengan kategori valid, Adapun peningkatan hasil dalam pengerjaan soal ditunjukan analisis data hasil belajar pre-test dan post-test dari hasil uji-t yang dilakukan dengan taraf kebenaran $95 \%$. Kelas XI IPS 2 Thitung > Ttabel adalah 3,23>1,68.

\section{DAFTAR PUSTAKA}

Muhajir, As'ari. (2011). Ilmu Pendidikan Perspektif Kontekstual. Jogjakarta: AR-RUZ MEDIA.

Piyanto, Dwi. (2009). Pengembangan Multimedia Pembelajaran Berbasis Komputer. INSANIA Vol. 14 No.1 Jan-April 2009.

Utomo, Dwi Wiji \& Kustijono, Rudi. (2015). Pengembangan Sistem Ujian online soal pilihan ganda dengan menggunakan software wondershare quiz creator. Jurnal Inovasi Pendidikan Fisika (JIPF) Vol. 04 No. 03, September 2015, 1-6.

Kustandi, Cecep. (2011). Media Pembelajaran Manual Dan Digita, Bogor, Ghalia Indonesia.

Sangkala, Ismail. (2014). Wondershare Quiz Creator Software Improves Students' Reading Comprehension. JKIP: FKIP Unismuh Makassar, Vol. 1 No. 2 Desember 2014. 
Binanto, Iwan. (2010). Multimedia Digital Dasar Teori dan pengembangan, Yogyakarta: CV Andi.

Setemen, Komang. (2010). Pengembangan Evaluasi Pembelajaran Online. Jurnal Pendidikan dan Pengajaran, Jilid 43, Nomor 3, Oktober 2010.

Herawati, Kuswari. (2009) Pelatihan Penyusunan Soal Matematika Interaktif Berbasis Web dengan Menggunakan Perangkat Lunak Bantu "Wondershare Quiz Creator. Makalah disajikan dalam kegiatan PPM, Indonesia, 13 November 2009 (http://www.wondershare.com/elearning/quizcreator/quizcreator_overview.html). Diakses 20 Juni 2019.

Sukmadinata, Nana. (2007). Metode Penelitian Pendidikan, bandung: PT Remaja Rosdakarya.

Hanum, Numiek Sulistyo. (2013). Keefektifan E-learning sebagai Media Pembelajaran (Studi Evaluasi Model Pembelajaran E-learning SMK Telkom Shandy Putra Purwokerto). Jurnal Pendidikan Vokasi, Vol. 3 Nomor 1, Februari 2013.

Setyosari, Punaji. (2010). Metode Penelitian Pendidikan dan Pengembangan, Jakarta: Kencana.

Candra, Rendik Uji. \& Achadiyah, Bety Nur. (2014). Pengembangan Media Evaluasi Pembelajaran dalam Bentuk Online Berbasis E-Learning Menggunakan Software Wondershare Quiz Creator dalam Mata Pelajaran Akuntansi SMA Brawijaya Smart School (BSS). Jurnal Pendidikan Akuntansi Indonesia, Vol. XII No. 1 Tahun 2014.

Mayer, Rihard E. (2009). Multimedia Learning. Surabaya: ITS Press.

Sanjaya, Wina. (2008). Strategi Pembelajaran Berorientasi Standar Proses Pendidikan. Jakarta: Kencana Prenada Media Group.

Arifin, Zainal. (2012). Evaluasi Pembelajaran. Jakarta: Direktorat Jenderal Pendidikan Agama. 